\title{
MEANINGFUL LIFE IS POSSIBLE WITH LOCKED - IN SYNDROME THE PERSONAL ACCOUNT OF A SURVIVOR
}

Dalibor Paspalj ${ }^{1}$, Petar Nikic ${ }^{2}$, Biljana Stojanovic ${ }^{1}$, Danijela Danilovic ${ }^{2}$, Igor Simanic ${ }^{4}$, Vladimir Jakovljevic ${ }^{3}$, Vladimir Zivkovic ${ }^{3}$, Stevan Jovic $^{1}$ ${ }^{1}$ Clinic for Rehabilitation "Dr. Miroslav Zotovic", Belgrade, Serbia

${ }^{2}$ Special Hospital for Cerebrovascular Diseases “Sveti Sava”, Belgrade, Serbia ${ }^{3}$ Department of Physiology, Faculty of Medical Sciences, University of Kragujevac, Serbia

${ }^{4}$ Special hospital for rehabilitation and orthopedic prosthetics "Rudo", Serbia

\section{NORMALAN ŽIVOT JE MOGUĆ SA “LOCKED-IN” SINDROMOM LIČNO SVEDOČANSTVO JEDNOG BOLESNIKA \\ Dalibor Paspalj ${ }^{1}$, Petar Nikić ${ }^{2}$, Biljana Stojanović ${ }^{1}$, Danijela Danilović2 Igor Simanic $^{4}$, Vladimir Jakovljević3 ${ }^{2}$ Vladimir Živković ${ }^{3}$, Stevan Jović1 ${ }^{1}$ Klinika za rehabilitaciju "Dr. Miroslav Zotovic", Beograd, Srbija \\ ¿Specijalna bolnica za kardiovaskularne bolesti "Sveti Sava”, Beograd, Srbija \\ ${ }^{3}$ Univerzitet u Kragujevcu, Fakultet medicinskih nauka, Katedra za fiziologiju, Kragujevac, Srbija \\ ${ }^{4}$ Specijalna bolnica za rehabilitaciju "Rudo", Srbija}

\begin{abstract}
Locked-in syndrome (LIS) is a rare condition characterised by quadriplegia and anarthria and is usually caused by a bilateral ventral ischemic pontine lesion. Patients are normally fully conscious, but their only mode of communication is with vertical eye movements and/or blinking. Although the mortality rate is high, it has been shown that patients can survive for a significant period of time. Once an LIS patient becomes medically stable, given appropriate medical care, his or her life expectancy may be several decades. LIS patients may suffer appreciably if they are treated by hospital staff as nonresponsive. Medical professionals and lay people often assume that the quality of life of an LIS patient is so poor that it is not worth living. However, the reported overall quality of life of LIS patients is not significantly different from that of healthy subjects. In this case report, we describe a 60-year-old retired man living in a locked-in state due to a brainstem infarct. His personal account vividly reveals his inner thoughts, a great deal of suffering, and his ability to cope with his condition throughout seven years of illness. LIS patients' early referral to specialist rehabilitation services and strong social support from family greatly improves LIS patients'their quality of life. Even limited physical recovery can improve quality of life and enable LIS patients to become active members of society and return to living with family.
\end{abstract}

Key words: locked-in syndrome, brain stem infarction, quality of life

\section{SAŽETAK:}

"Locked-in" sindrom (LIS) ili sindrom "zarobljenosti u sopstvenom telu", je redak hronični poremećaj u kome bolesnici nisu u stanju da se pomeraju ili da govore, ali imaju potpuno očuvanu svest. LIS najčešće nastaje zbog opsežne lezije ventralnog dela ponsa, izazvane trombozom bazilarne arterije. Mortalitet je visok u prvim mesecima nakon doživljenog insulta ali bolesnici po stabilizaciji stanja mogu da prežive i nekoliko desetina godina, ako im je obezbeđena adekvatna medicinska nega. Osobe sa ovim sindromom mogu veoma da pate ukoliko medicinsko osoblje ne prepozna da se radi o nepokretnim bolesnicima koji su potpuno svesni. Zdravstveni radnici i laici često smatraju da je kvalitet života u LIS veoma loš, ali se on ne razlikuje značajno u odnosu na zdrave osobe. U ovom prikazu opisujemo bolesnika, starog 60 godina, koji živi u "locked-in" stanju poslednjih sedam godina nakon doživljenog infarkta moždanog stabla,. Njegovo lično svedočanstvo, otkriva na impresivan način, unutrašnja razmišljanja, veliko odricanje i patnju kroz koju prolaze ovi bolesnici, uz istovremenu rešenost da se bore sa svojom bolešću. Rano uključivanje bolesnika u rehabilitacioni tretman, kao i snažna podrška članova porodice veoma značajno utiču na kvalitet života osoba sa LIS jer čak i minimalno poboljšanje motornih funkcija značajno poboljšava kvalitet života i omogućava im da žive u sklopu svoje porodice i postanu korisni članovi društva.

Ključne reči: locked-in sindrom, infarkt moždanog stabla, kvalitet života

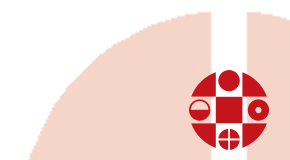

\section{LIST OF ABBREVIATIONS:}

ALIS - Association du Locked-in Syndrome

CT - Computed tomography

ICU - intensive care unit

LIS - locked-in syndrome 


\section{INTRODUCTION}

Locked-in syndrome (LIS) is a rare condition characterised by quadriplegia and anarthria and is usually caused by bilateral lesions of the ventral part of the brainstem. The patient is fully conscious and aware but unable to communicate intelligibly, except by using vertical eye movements or blinking. The most common aetiology of LIS is an atherosclerotic basilar artery disease leading to ischemic lesions that disrupt corticospinal and corticobulbar pathways passing through the basis pontis. The term "LIS" was coined in 1966 by Plum and Posner, emphasising the state in which the victim is fully alert but virtually "locked" inside an immobile body (1). Formal criteria for the diagnosis of LIS in adult patients with severe brain injury were proposed by the American Congress of Rehabilitation Medicine. The authors defined LIS as a condition in which all of the following are present: 1 ) eye opening is well sustained (bilateral ptosis should be ruled out); 2) basic cognitive abilities on clinical examination are preserved; 3 ) evidence of hypophonia or aphonia is present; 4) quadriparesis or quadriplegia is present; and 5) the primary mode of communication is through eye movements or blinking (2). Based on clinical findings, Bauer subdivided LIS patients into three groups: a) classical LIS (only conjugated vertical eye movements or blinking are retained), b) total LIS (complete loss of any voluntary movement including eye movement), and c) incomplete LIS (signs of classical LIS plus remnants of other voluntary muscle action). In addition, Bauer separated transitory from chronic LIS forms (3). In addition to vascular pathology (occlusion of the basilar artery or a pontine haemorrhage), there are sporadic reports in the medical literature of other causes of LIS. The most important nonvascular conditions that may resemble LIS are brain stem injury (traumatic LIS), primary or secondary malignant infiltration of the basis pontis (neoplastic LIS), and central pontine myelinolysis (metabolic LIS) $(4,5)$. In addition, there are case reports of inflammatory, infective, toxic, and various other causes of LIS $(6,7)$. A transitory locked-in state has occasionally been observed in subjects with an acute inflammatory polyradiculoneuropathy, with a postinfectious neuropathy, or under general anaesthesia when receiving an insufficient amount of a muscle relaxant drug (8-10). Finally, a state that is identical to LIS can be observed in the final stage of motor neuron disease (11). In this case report, we describe a patient with ischemic LIS and his personal account of the disease.

\section{CASE OUTLINE}

It was an ordinary cloudy autumn day in Belgrade, the economic and political capital of Serbia. A 53-year-old male accountant was going to his job, deeply immersed in thoughts about the day ahead. Upon arriving at the parking lot in front of his office, he suddenly felt debilitating pain in the neck and posterior part of the head.
Later, he vividly described his condition at that moment: "It was the worst pain I ever had. I thought that something was tearing me apart from the inside. It was like watching TV and the program suddenly went out completely. Suddenly, all I could see was black and white dots, as if there was no TV signal, only the lingering static in my head. I was fully conscious but fell down on the ground shaking all over from the sheer frustration and that terrible pain". Soon afterwards, people passing nearby called emergency services. Within 20 minutes of the onset of symptoms, he was transferred by an ambulance to the emergency department of a university hospital. One hour later, his vision cleared, and he found himself lying on a cold flat surface, completely weakened, with no ability to move his limbs or utter a word. From the ambient sounds and the medical jargon used by the people around him, he deduced that he was in a busy emergency department. His past medical history, obtained from relatives, was unremarkable except for untreated mild arterial hypertension. He also had a healed fracture of the jaw, stabilised with a metal implant, from a traffic accident that took place ten years prior. He lived with his wife and children. He did not smoke but drank alcohol occasionally. Computed tomography (CT) of the head performed without the administration of contrast medium was normal. Blood pressure was $220 / 120 \mathrm{mmHg}$, pulse was 140 beats per minute, and axillary temperature was $38.5^{\circ} \mathrm{C}$. His respiration was shallow but regular, with 10 breaths per minute. The general physical examination was otherwise normal. On neurologic examination, the neck was supple and the pupils of equal size and reactive. $\mathrm{He}$ was lethargic, opening his eyes on request, but there were no other spontaneous or voluntary ocular movements. No facial movements were detectable, and he had total paralysis of the tongue and oropharyngeal musculature. Voluntary limb movements were not observed, but painful stimulation of either the arm or leg caused a decerebrate posture. Both plantar responses were extensor. A limited sensory examination revealed no abnormalities. After the initial evaluation, the trachea was intubated for airway protection, and a nasogastric tube was inserted. Thrombolytic therapy was not considered as a possible treatment because it was not a standard procedure at the time. Aspirin was administered through the nasogastric tube, lowmolecular-weight heparin was given subcutaneously, and the patient was transferred to the neurology department for further diagnostic workup. Basic blood chemistry tests were normal, except for mild hyperlipidemia with total cholesterol of 6, 02; low-density lipoprotein cholesterol of 3,62 ; high-density lipoprotein cholesterol of 1,27; and triglycerides of 2,05 millimoles per litre. The white cell count was 14,300 per $\mathrm{mm}^{3}$; the hematocrit $44,6 \%$, and the platelet count 230,000 per cubic millimetre. Routine tests of blood coagulation were normal. Lumbar puncture revealed clear cerebrospinal fluid, with 40 erythrocytes per $\mathrm{mm}^{3}$ and 1 leukocyte per $\mathrm{mm}^{3}$. The protein level was 0,22 grams per litre, and the glucose level was 4,0 millimoles per litre. An electrocardiogram was normal. A chest radiograph re- 
vealed clear lungs and a normal cardiomediastinal silhouette. Additional cerebral and neurovascular imaging (CT, transcranial Doppler) performed 3 and 7 days later showed bilateral ischemic lesions in the basis pontis and stenosis in the middle part of the basilar artery.

He recalled from his first days of hospitalizisation, "The first few weeks spent in the hospital were the most horrifying period in my life. In the intensive care unit, the busy medical staff was proceeding with their daily routine treating me as any other unresponsive patient with a severe brain injury. All I could detect from their indifferent faces and manners was the revelation of approaching doom. I wanted to scream out my helplessness and frustrations, but all was in vain. The inability to sleep and the agonising pain, my constant and faithful companions, made death seem a good alternative to me. The tiny thread that kept my sanity in check was the precious moment during visiting hour when I could hear comfort from my loved ones."

After three weeks, he was transferred, due to a shortage of beds, to another hospital for further treatment. At discharge, he was lying motionless on a stretcher, still intubated, looking straight ahead as if at an invisible dot in front of him. To a casual observer, only the voluntary use of vertical eye movements and blinking revealed that a fully conscious human being was present. He had fulfilled all clinical criteria for the diagnosis of classic LIS.

Thinking about the time spent at the second intensive care unit (ICU) brings him somewhat more congenial memories: "I was lying in a hospital bed, surrounded by monitors and machines, with their incessant beeping and buzzing as a constant reminder that I was once again in the ICU. However, with each passing day, I learned bit by bit to cope with my situation. I tried to find comfort in small things, like a smile or a few calming words from the attending nurse. The particular moment when, for the first time, one doctor looked into my eyes and spoke to me as a person engraved itself into my memory. Her soothing and gentle words were balm to my soul. After a several weeks I was extubated. What a relief, breathing ambient air again!" Two months after the brain stem stroke, with a diagnosis of LIS due to bilateral infarct of the ventral part of brain stem, he was moved to a rehabilitation clinic, where he spent an additional six weeks in intensive physical therapy.

He concluded his narration, "The bed sores caused me much discomfort and affected my ability to cooperate. The constant pain that I felt in my knees and heels from being in the same position for hours was almost unbearable. If people could only imagine how a small, seemingly trivial part of the regular nursing routine, such as the manoeuvre that keeps near joints from rubbing each other while moving the patient from their back onto their side, may be of such enormous importance for the completely paralysed person."

Three months after the stroke, he was discharged to go home with no visible functional improvement. He stated firmly that his family's support and caring was a turning point in his ability to cope with the disease. "The discharge to in-home care was the decisive moment in my illness. I was mentally and physically very weak, but with the unconditional love and support of my loved ones, every passing day provides a new ray of hope and gives me the reason to fight back even more. It was not an easy journey, but within months, my bed sores healed and the pain, my constant companion for months, was almost gone. Gradually, I managed to feebly move my head to the left side, and maintain a sitting position in a wheelchair with back support. I still couldn't speak, but after sixth months I managed to communicate by blinking and using tiny movements of the head and right hand. With the help of my daughter, I devised a code, using for each letter of the alphabet a previously determined combination of various signs. After a little bit of practice, she could easily, from two or three of my incompletely spelled words, make a meaningful sentence by guessing the missing parts. At last, I was able to accurately convey my inner thoughts to someone else." With this, he concluded his remarkable story.

In the first year of his illness, he suffered from occasional periods of insomnia that could last for up to four nights in a row. The resulting emotional lability and drooling made it difficult for him to create and retain social contacts, and his inability to voluntarily control breathing frustrated him. Fortunately, he was free of any serious medical complications, with the exception of recurrent crural deep vein thrombosis, which was successfully treated with lowmolecular-weight heparins. Now, almost seven years after the stroke, he has regained some movement of the tongue and the neck but is still unable to produce meaningful speech or sit unsupported. He has gradually regained a degree of independence, allowing him to use an electric wheelchair for mobility. He uses a computer to access the Internet, keep up with social contacts through e-mail, and play games (Figures 1 and 2). Nonetheless, due to prolonged immobility and lack of no verbal communication, he has been able to remain in contact with only a few of his former friends and colleagues. In the warm months, he en-

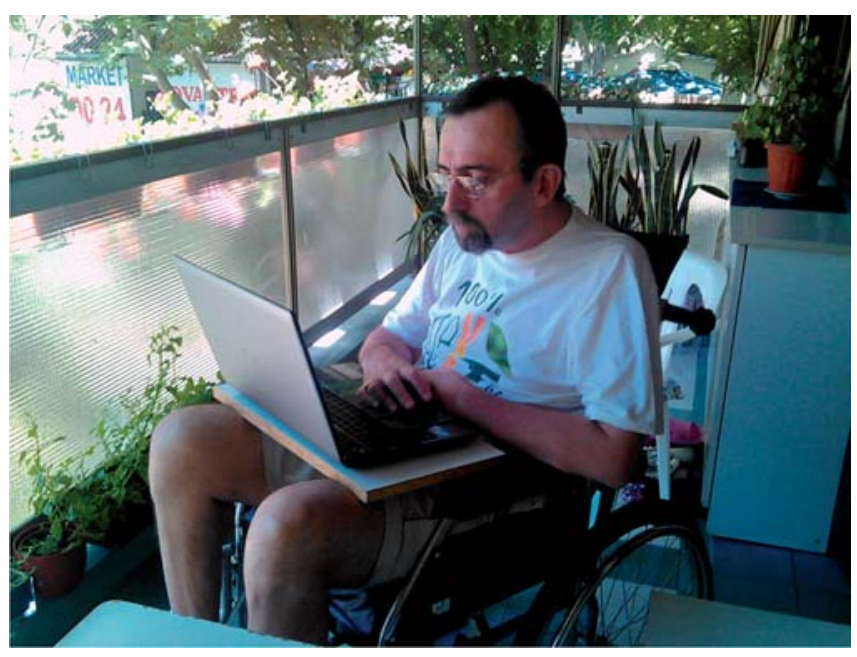

Figure 1. The patient works at a computer, which has become an indispensable part of his daily life.

Consent was obtained for publication of the story and figures. 


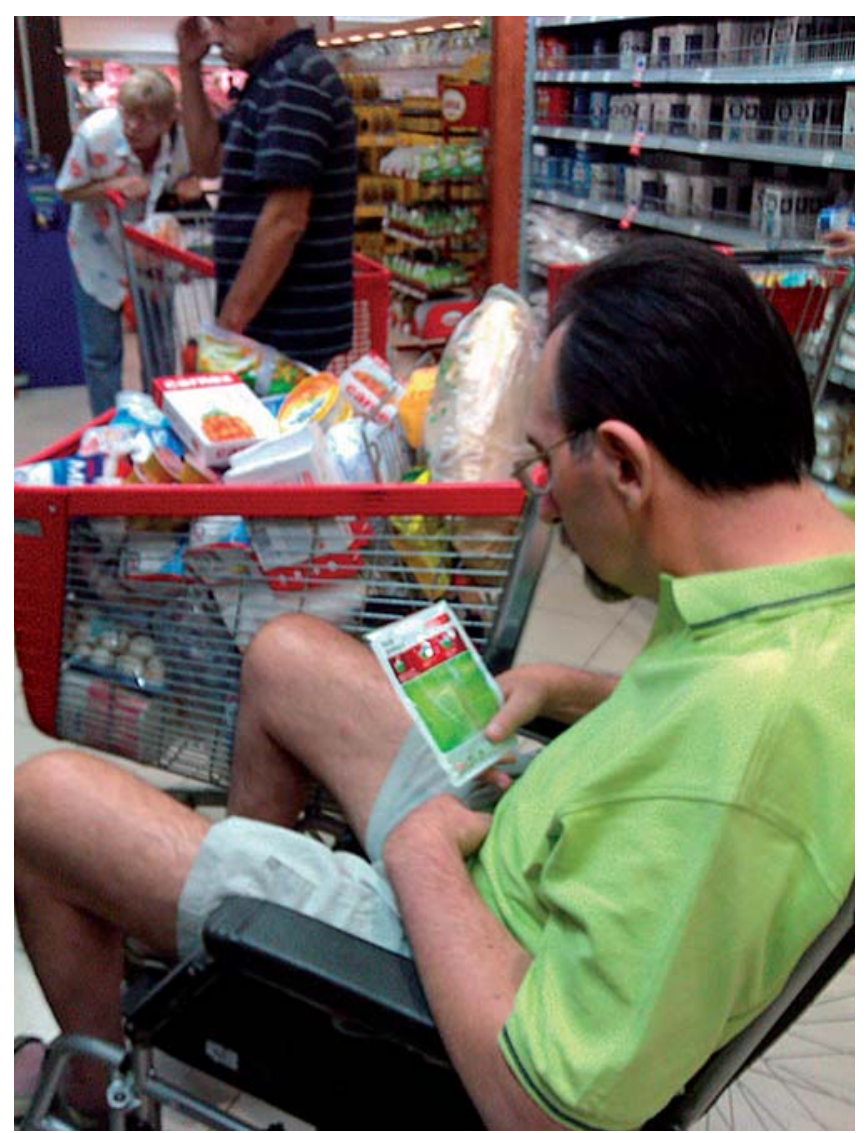

Figure 2. The patient shops at the supermarket. The patient now finds time to enjoy and appreciate day-to-day activities.

Consent was obtained for publication of the story and figures.

joys spending time outdoors with his family and relatives. He concludes that his quality of life has improved primarily due to his willingness to cope with his disease, but it would all be in vain if it were not for the unconditional love and understanding of his family.

\section{DISCUSSION}

The outcome for patients with LIS is directly related to the disease aetiology and the patient's age at disease onset. A vascular aetiology is found in $86 \%$ of 320 subjects listed in the world's largest database of subjects with LIS ("Association du Locked-in Syndrome", ALIS), and brain stem infarct is reported as the most frequent cause (12). The overall prognosis and the degree of functional recovery are much worse for patients with vascular LIS than non-vascular LIS. Systemic and pulmonary infections are the leading causes of death in patients who survive the acute phase. Functional recovery from vascular LIS is very limited. However, there are case reports of substantial motor improvements after intensive and early rehabilitative treatment applied in the first months following the disease onset. Recently, it has been shown that the prognosis in chronic LIS (more than one year in a locked-in state and medically stabilised) is much more favourable than previously thought (13). The 20-year survival rate ranges from 31 to $40 \%$ (14). Insomnia and emotional lability (87\% of patients) are well-known complications in patients with chronic LIS (15). LIS patients with lesions in the ventral pons and superior medulla are prone to problems with voluntary control of breathing because the respiratory brainstem centres are often damaged as well (16). Despite a widespread belief to the contrary, profound motor deficits and a limited capability for social interaction do not preclude these patients from having a rich and meaningful life. Almost half of the patients listed in the ALIS database return home. For those who are unfamiliar with chronic LIS patients, the reported scope of social participation and recreational activities is surprising. Some surveys show that more than $70 \%$ enjoy going out, and $80 \%$ of patients diagnosed with LIS meet with friends several times per month. Nearly half of them describe their mood as good, and up to $30 \%$ report active sexual relations. Furthermore, nearly $75 \%$ are able to participate in recreational activities, such as hobbies, sports, and games. It has been noted, as in our case report, that the factor that most helps LIS patients to cope with their disease is social support from family and close friends. On the other hand, caring for patients in a lockedin state places an enormous burden on the caregivers. Interestingly, in a group of patients with LIS caused by brainstem infarct (17 patients, mean LIS duration 6 ys.), the subjective quality of life was not related to physical limitations, nor could it be predicted by the degree of motor impairment. The public's negative view of LIS patients' quality of life may be explained by the idea that healthy people may have difficulty imagining the emotions and experiences of severely impaired patients (see the excellent discussion of psychosocial adjustment to LIS, from Lulé et colleagues , 2009). The authors conclude that the overall quality of life in a locked-in state is not significantly different from that of healthy subjects (17).

\section{CONCLUSION}

Patients in a locked-in state may return to live at home and begin a new, very different, but satisfactory life, if they have adequate medical treatment and physical rehabilitation. Significant and continuous social support from the family is of the outmost importance for LIS patients. We hope that this case report emphasises the fact that the majority of LIS patients have the potential to achieve a meaningful quality of life and become productive members of society.

\section{ACKNOWLEDGEMENTS}

This work was supported by Grant No. 175043 from the Ministry of Science and Technical Development of the Republic of Serbia.

\section{CONFLICT OF INTEREST}

The authors declare that they have no conflicts of interest. 


\section{REFERENCES}

1. Posner JB, Saper GB, Schiff ND, Plum F. Plum and Posner's Diagnosis of Stupor and Coma. 4th ed. New York: Oxford University Press, 2007

2. American Congress of Rehabilitation Medicine, Recommendations for Use of Uniform Nomenclature Pertinent to Patients With Severe Alterations in Consciousness. Arch Phys Med Rehabil 1995; 76: 205-9.

3. Bauer G, Gerstenbrand F, Rumpl E. Varieties of the Locked-in Syndrome. J Neurol 1979; 221: 77-91.

4. Patterson J, Grabois M. Locked-in syndrome a review of 139 cases. Stroke 1986; 17: 758-64.

5. Smith E, Delargy M. Locked-insyndrome. BMJ 2005; 330: 406-9.

6. Murphy MJ, Brenton DW, Aschenbrener CA, Van Gilder JC. Locked-in syndrome caused by a solitary pontine abscess. J Neurol Neurosurg Psychiatry 1979; 42: 1062-5.

7. Pirzada N, Ali I. Central Pontine Myelinolysis Case report. Mayo Clin Proc 2001; 76: 559-62.

8. Ragazzoni A, Grippo A, Tozzi F, Zaccara G. Eventrelated potentials in patients with total locked-in state due to fulminant Guillain-Barre syndrome. Int J Psychophysiol 2000; 37: 99-109.

9. O’Donnell P. 'Locked-in syndrome' in postinfective polyneuropathy. Arch Neurol 1979; 36: 860.
10. Sandin RH, Enlund G, Samuelsson P, Lennmarken C. Awareness during anaesthesia: a prospective case study. Lancet 2000; 355: 07-11.

11. Kotchoubey B, Lang S, Winter S, Birbaumer N. Cognitive processing in completely paralyzed patients with amyotrophic lateral sclerosis. European Journal of Neurology 2003; 10: 551-58.

12. Bruno MA, Pellas F, Schnakers C, et al. Le LockedIn Syndrome: la conscience emmurée. Revue Neurologique 2008; 164(4): 322-35.

13. Casanova E. Locked-in syndrome: improvement in the prognosis after an early intensive multidisciplinary rehabilitation. Arch Phys Med Rehabil 2003; 84(6): 862-67.

14. Doble JE, Haig AJ, Anderson C, Katz R, et al. Impairment, activity, participation, life satisfaction, and survival in persons with locked-in syndrome for over a decade: Follow up on a previously reported cohort. J Head Trauma Rehabil 2003; 18: 435-44.

15. León-Carrión J, Eeckhout PV, Domínguez-Morales MDR. Review of subject: The locked-in syndrome: a syndrome looking for a therapy. Brain Injury 2002; 16(7): 555-69.

16. Heywood P, Murphy K, Corfield D. Control of breathing in man; insights from the "locked-in" syndrome. Respiration and Physiology 1996; 106: 13-20.

17. Lulé D, Zickler C, Häcker S, et al. Life can be worth living in locked-in syndrome. Prog Brain Res 2009; 177: 339-51. 